\title{
FINANCING AND INSTITUTIONAL MODELS OF SOY PRODUCTS
}

\author{
Zainuri, M. Saleh, Nur Hisamuddin, Agus Mahardiyanto \\ University of Jember, Jember, Indonesia \\ zainuri.feb@unej.ac.id
}

\begin{abstract}
Discourse on the development of soybean processed products is important to study because besides being able to uncover the question related to the low productivity of soybean cultivation also gives a clue as to why soybean processed product entrepreneurs have almost no accumulation of capital so far. This study aims to reveal financing models and institutional patterns of soybean processing businesses in Jember district. This type of research will use qualitative research from an emic perspective that will be implemented in the area of Jember Regency. The type of data used is primary and secondary data which are then processed and analyzed using the Miles and Huberman analysis method. This study found that the development of soybean processing business, which consisted mainly of MSME entrepreneurs, was enticed by a financing model whose funds were mostly supplied by the Suwek Daily Bank (BHS) and loan sharks that caused the profit margins to not be enjoyed by the entrepreneurs themselves. In addition, the institutional patterns built between soybean processed products entrepreneurs such as tempeh, tofu, milk and soybean snacks are still weak. They individually compete more freely so that when there is a shock such as an increase in the price of imported or local soybeans it will sacrifice quality. Some build a vertical partnership pattern between soybean processed product entrepreneurs and their raw material suppliers and with soybean processed users, while horizontally between processed product entrepreneurs barely build partnerships. This condition causes unfair competition between businesses and ultimately increases the transactions cost of economic that will erode the margins they earn.
\end{abstract}

Keywords: Partnership Pattern, Qualitative Model, Transactions Cost of Economic

\section{Introduction}

Indonesia has the nickname as an agricultural country because it has abundant natural wealth, especially in the field of agricultural resources because Indonesia has fertile land and a climate that supports the growth of various types of plant varieties. Besides that, since the days of our ancestors Indonesia had knowledge of agriculture and irrigation techniques that were stored in local wisdom and culture of the community. Thus, agricultural commodities in Indonesia need more attention from the government, especially agricultural commodities which are processed into basic needs for the community. The affordability and stability of prices of basic commodities in the domestic market such as rice, wheat flour, granulated sugar, cooking oil and soybeans by the lower classes are the main indicators of the success of an agrarian country.

The agricultural sector has a large role in national development through the formation of GDP (Gross Domestic Product), providers of employment, community income sources, reducing poverty, obtaining foreign exchange through exports and creating national food self-sufficiency and in creating conducive conditions for the development of other sectors.

Soybean is ranked as the third most important commodity in Indonesia after rice and corn. More than 90 percent of Indonesian soybeans are processed as food, which is around 88 percent for tofu and tempeh, 10 percent for other processed foods 
and around 2 percent for seeds. Soybeans have a variety of benefits as well as a fairly high number of nutritional adequacy causing soybeans to be a product that is quite attractive to the people of Indonesia. Some processed foods made from soybeans consumed by most Indonesian people include tofu, tempeh, soy sauce, soy milk, tauco and so on.

Processed products made from soybean have a strategic value because besides being affordable and relatively stable, also because of the level of demand that is evenly distributed from all walks of life both in rural and urban areas, in traditional markets and modern markets. The majority of producers of soybean processed food products are owned by micro, small and medium class entrepreneurs. Shock to soybean prices both due to crop failure and rising prices of imported soybeans due to the appreciation of the US Dollar will result in social unrest among consumers and producers of processed products from industry, livestock and other processing.

The smooth development of soybean processed products is influenced by productivity, soybean land area and imports. Data from Bank Indonesia research (2018) recorded since 1980 -2016 there was an increase in soybean production by an average of $1.36 \%$ for the Java region, while there was an extraordinary increase outside Java as much as an average of $6 \%$ per year. Ironically, there has been a decline in the average production growth in the past five years by $0.14 \%$ and even on Java it has actually decreased by an average of $2.44 \%$ per year.

The majority of soybeans are consumed in processed forms, especially tempeh and tofu as much as $50 \%$ and $40 \%$, respectively. The rest is made into other forms such as soy sauce, tauco or others. For more than ten years from 2002 to 2015, consumption of tempeh was $7.48 \mathrm{~kg} /$ capita / year. This figure does not differ much from the average consumption of the Indonesian population to tofu at $7.26 \mathrm{~kg} /$ capita / year. While consumption of soy sauce is only $0.65 \mathrm{~kg}$ / capita / year (SUSENAS).

Most of the businessmen of soybean processed products in Jember Regency come from MSMEs. From Jember data in 2017, it is stated that as many as $45.15 \%$ of micro entrepreneurs, $39.52 \%$ are small businesses and only $15.33 \%$ are medium entrepreneurs. Entrepreneurs like this are vulnerable in penetrating financing access to formal financial institutions for not bankable reasons either because of their weak business portfolio, economies of scale, parashible products, dependence on nature, and weak institutional development. This is compounded by dependence on imported soybeans. If there is a fluctuation in exchange rates like what happened recently or an increase in the price of soybeans in the international market due to problems that occur in the producing country, then it is susceptible to cause anxiety from entrepreneurs made from soybeans.

The weak supply chain of soybean-based products and the lack of partnerships between business actors will be a crucial point for the development of soybean-based products. The purpose of this study is to develop a business financing model of derivative products made from soybeans for soybean entrepreneurship and institutional models of soybean derivative products in strengthening its Value Chain. 


\section{Research Method}

This research is a type of survey and exploratory research that will be carried out in several sub-districts of Jember Regency by using a qualitative approach. The stages of the research are conducting in-depth observations and interviews as well as focus group discussions on soybean-based products. Then an analysis of the financing model and institutional patterns of soybean-based products are expected to be able to strengthen the supply chain. The type of data used in this study are primary and secondary data. Primary data is in the form of perceptions / opinions of informants on the financing models of their business, both formal and informal. While secondary data is in the form of data on the development of business made from soybeans, production data on sales volume data and partnerships carried out both with suppliers and with users of their products. The data collection method used in this study is the documentation method to explore secondary data in the form of supplier data, production and sales data and business financing models made from soybeans. Methods An indeph interview is conducted to explore data on the financing system and financial reports obtained from business actors processed products made from soybeans, Islamic financial institutions and small-scale soybean-based businesses. Focus Group Discussion (FGD)

Used to collect data as well as solving the problems raised in the research that will look for solutions to problem solving in groups refers to the facts that exist by involving stakeholders and experts / experts. Analysis Method Data in this study used qualitative exploratory descriptive. Descriptive-exploratory qualitative approach is used to describe and explain the problems faced by soybean-based products. Furthermore, analysis from Miles and Huberman was used to explore the financing model and institutional patterns of soybean-based products.

\section{Finding and Argument}

The role of MSMEs, including those engaged in soybean processing in the national economy, has increased, especially after the 1997 crisis. When banks faced difficulties in finding debtors who did not have problems, MSMEs became an alternative bank lending. However, banks tend to favor non-micro businesses rather than micro-enterprises. Banks are so easy to provide loans to non-micro businesses but it is difficult to provide loans to micro-businesses. Micro businesses generally find it difficult to meet the requirements proposed by the bank. The current funding model involves funders and formal and non-formal financial institutions that have been trusted by the government to channel financial assistance to MSMEs. The financing model faced by business actors in processed products made from soybeans from small and medium / large businesses has a different path.

The following are some explanations of the forms of funding cooperation carried out by soybean product business actors:

a. Small / micro businesses 
Capital sources for small businesses are more likely than non-formal financial institutions. There are several sources of capital for small businesses, the first is input suppliers, for cooperation in the form of in-kind that is done by providing loans in the form of raw materials to soybean derivatives businesses which will later be returned in the form of cash deposits worth the raw materials when they will take loan again. This is done continuously as long as production activities are still running. Furthermore, capital sources come from non-formal financial institutions (cooperatives, KUD, loan sharks)

\section{Soybean Derivative Product Financing Model}

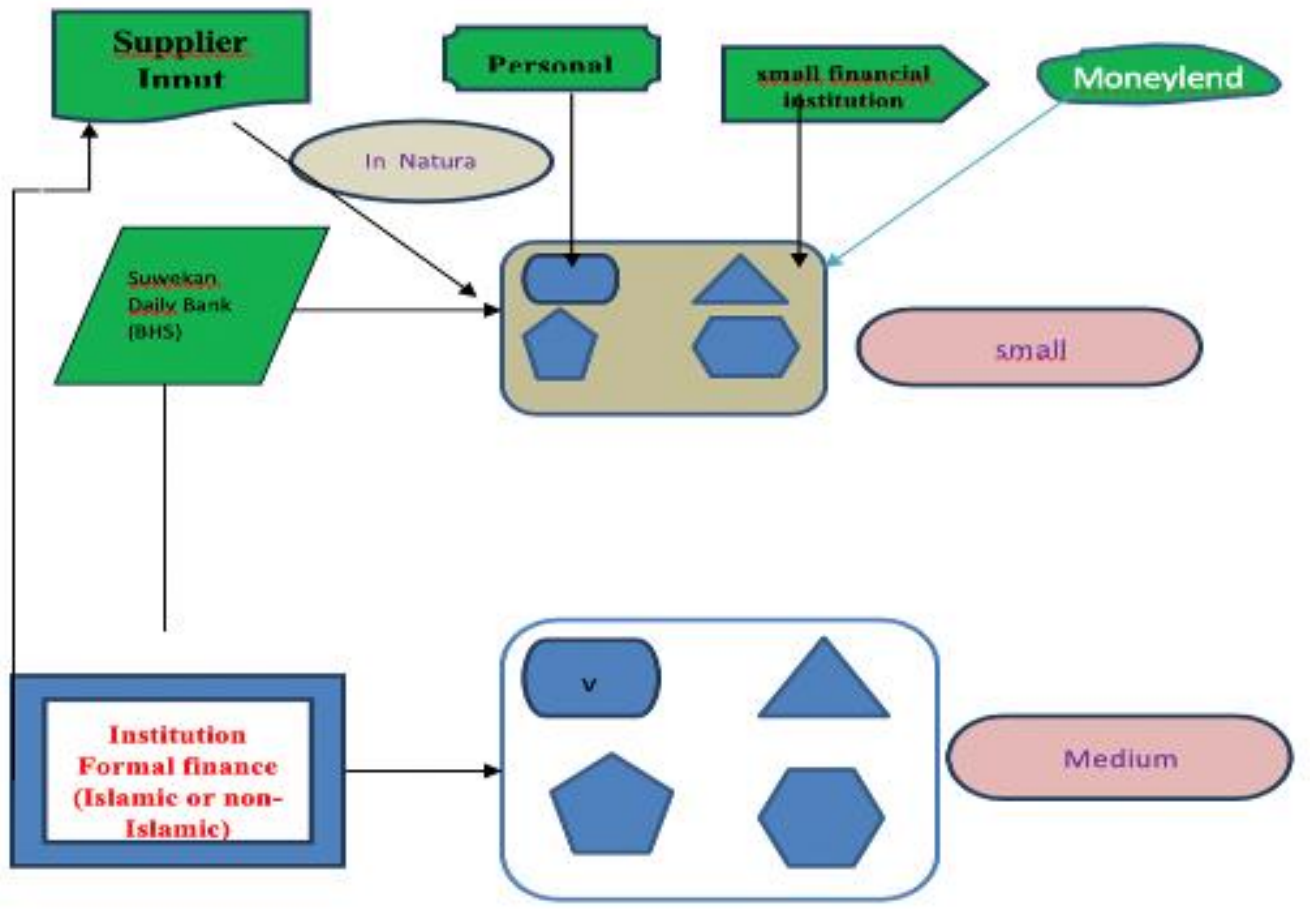

In the form of a term loan, where the loan is a number of funds for a certain period and a certain interest rate. For loan sharks, loans can reach $50 \%$ of the total loan and the longer the customer returns the loan from maturity, the more interest will be added. Then, another source is the Suwekan Daily Bank (BHS) which is a small-scale private bank run by individuals. Customers from BHS generally are traders in the market and small entrepreneurs. Customers from BHS do not need to open a savings account in advance to be able to borrow funds, anyone can borrow funds from BHS provided they are able to repay the loan. The BHS will provide a note paper such as receipts to borrowing customers as evidence if they have taken a loan from BHS and will later be signed into the BHS bookkeeping system. In addition, the source of capital can also come from the business owner's personal funds.

b. Medium / large businesses

Capital sources for medium / large businesses generally come from formal financial institutions such as conventional banks. Medium / large businesses are easier to get access to funding from banks because generally medium / large businesses already have business licenses and are officially registered with the service. This makes 
the bank feel guaranteed to give funds to middle / large businesses. In addition to carrying out medium / large business loans, it can also apply for the purchase of a production machine to the bank, which will then be paid in installments by the businessman to pay off the machine that has been given.

Based on the results of surveys and observations of entrepreneurs using soybean derivative products, there were no sources of shari'ah capital. Entrepreneurs are not so concerned about where the sources of funds come from, either from formal or non-formal financial institutions or the Shari'ah and syari'ah institutions. During the process of fast disbursement of funds and easy requirements wherever the source of funds is not a problem. Because the funding needs at that time can be a guarantee of continuing business in the future.

Another case with research from Bank Indonesia (BI) with the same theme, namely, financing the business of processed soybean products. Syari'ah financing was found in the business of soybean processed products where the financing generally used murabahah and musyarakah contracts.

The financing model that is expected to strengthen the supply chain

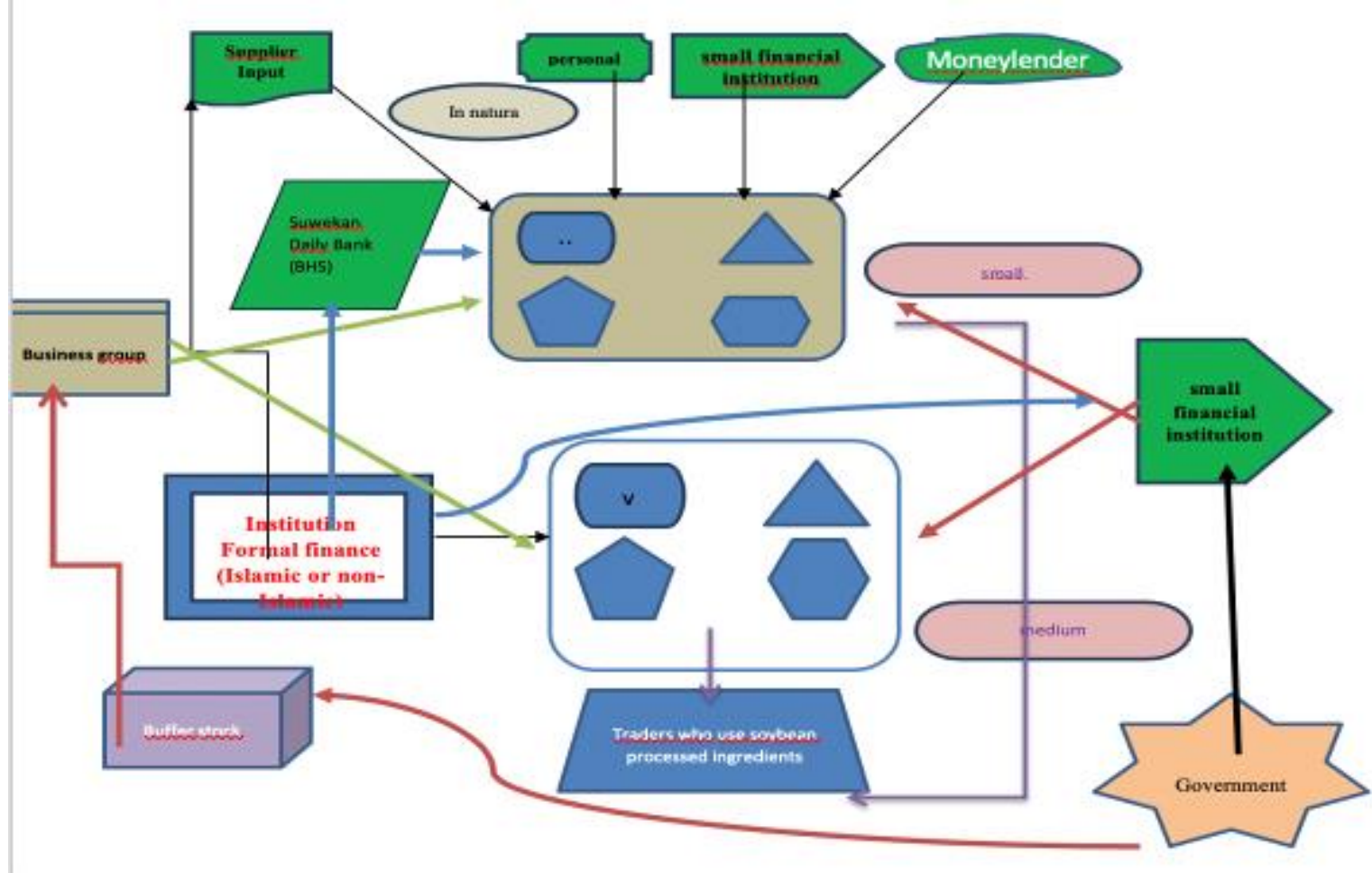

MSMEs is the backbone of the economy in Indonesia because it is naturally more dynamic than large companies. Hiring the World Bank, Indonesia's own source of livelihood relies heavily on the MSME sector. And overall, the MSME sector is estimated to contribute around more than 50\% of GDP (mostly in the trade and agriculture sectors). The 2014 BPS data shows that MSMEs contributed greatly to providing employment opportunities of $96.99 \%$ to the formation of GDP of $60.34 \%$. MSMEs also have achievements that are quite proud of the relatively small level of credit congestion. In 2002, NPLs of MSME loans were only 3.9\%, far smaller than the 
total bank loans which reached $10.2 \%$. Therefore, the government should pay more attention to the MSME sector in order to develop and be able to compete in the current free market era.

In connection with resolving capital issues, the government has issued and rolled out (KUR). However, this program cannot be fully absorbed by MSMEs, especially for micro-enterprises. Micro businesses have not been able to fulfill several requirements documents requested by KUR executing banks. In addition, the problems experienced by MSMEs are not only capital problems, but also problems related to marketing and managerial matters. Therefore a program formulation is needed which can answer all MSME problems. The program in question must be able to answer the main MSME issues relating to capital and other issues related to marketing. So it is necessary to formulate a financing scheme that accommodates all MSME issues.

This financing scheme is expected to run well according to the expectations of researchers, namely:

Financing is channeled directly to MSMEs through banking. Middle / large businesses can apply for loans directly to the bank as long as they are able to complete the requirements submitted by the bank. Banks can also channel their funds through small financial institutions such as Bumdes, Suwekan Daily Bank (BHS), input suppliers, which will be addressed directly to MSMEs both micro and macro businesses.

The role of the government in providing raw materials and maintaining the stability of raw material prices is very important for the business continuity of MSMEs. This role can be through the buffer stock institution (bulog) which will later be channeled again to business groups and from business groups to be distributed to MSMEs. In addition, the government / related offices can also use Bumdes as a buffer stock institution that serves MSMEs in the village autonomous region

\section{Conclusion}

Based on the analysis of the results of the research and discussion described earlier, the conclusions in this study are:

1. Horizontal institutions are not very good for soybean derivative products. While institutions vertically are still interwoven individually, for example in the form of financing models in the form of take-away and it is built with a high sense of trust.

2. Weak production and post-harvest technology that makes it difficult for products to develop, for example, how to deal with processed products to be more durable without using chemicals. Because the preservative technology has not yet been found, the average soybean processed products are in elastic and have difficulties in achieving higher profits.

3. Buffer stock or an institution that provides certainty of quality raw materials at stable prices is needed by soybean product businessmen but this is having problems: Most of the quality of local soybeans is very low due to high 
production costs including MSE or UMR which is increasing every year and the difficulty of boosting soybean prices so that there is dependence on imported soybeans

4. The market structure of processed products is generally competitive, this is caused by weak horizontal institutions, the market structure results in a price war (does not increase prices but reduces quality such as mixing soybeans with arinya skin or corn for tempeh products) sule replaces sugar with artificial sweeteners)

5. The financing model of processed soybean products can be distinguished between small entrepreneurs and medium / large entrepreneurs. For small entrepreneurs, more financing is from personal funds or partnerships with raw material suppliers or with microfinance institutions / loan sharks. For partnerships with suppliers, it is done by in-kind / non cash models that are carried out on the basis of trust. This model is quite efficient. Whereas capital from microfinance institutions is rather burdensome for entrepreneurs of soybean derivative products

6. For middle-class entrepreneurs more use of formal banking financial institutions, both conventional banks and Islamic banks. Especially by utilizing the KUR funding scheme, the selection of a financing model on the basis of conventional or sharia is not too important to differentiate because the consideration of entrepreneurs is more oriented to the ease and low transaction costs

7. The institutional model that is expected to strengthen supply chain is the presence of a buffer stock institution that is able to penetrate so that inputs are guaranteed to be available at stable prices, in addition the government is expected to provide input and output subsidies both directly to business groups and through buffer stock institutions

8. The design of partnership between soybean processing businessmen and merchants (such as meatball traders, cilok, mlijo who use soybean processed ingredients) and with other entrepreneurs (such as hospitals, photocopies, pharmacies) in the form of profit sharing is needed to reduce transaction costs

9. Institutions of soybean derivative products such as tofu factories, tempeh, soybean snacks, soybean milk and others as a whole have not taken advantage of opportunities from formal financial institutions such as banking. There are several parties involved in marketing soybeans, such as: whole sales, sales agents, brokers / middlemen, small collectors

\section{Ackknowledgment}

I thank the ministry of research and technology (DRPM) for providing funding support in this research. We also thank the Rector of University of Jember. 


\section{References}

Adisarwanto, (2008), Budidaya Kedelei Tropika, Jakarta:PenebarSwadaya

Bank Indonesia (2018), Pola Pembiayaan dan usaha pengolahan kedelai, kantor perwakilan bank Indonesia Cirebon

BPS, Jember dalam angka (2017)

Dharmawan, Arya Hadi (2001), Form Household Livehood Strategies and SocioEconomyChangesin Rural Indonesia : A Comperative Study. Socioeconomics Study on Rural Develepment, Vol 124, Wissenschftsverlag Vauk Kiel KG

Darni lamusu dkk, ?, Sistem Dinamik Kebijakan Penyediaan untuk Industri Kedelai, Makasar:Universitas Hasanudin.

Deliarnov ( 2006), Ekonomi Politik, Jakarta:Gelora Akasara Pratama

Erwan, Agus Purwanto (2010), 'Kebijakan Publik Dalam Kancah Peradaban Dunia Yang Terbelah: Memahami Politik Etnis dalam Perumusan Kebijakan Publik' Universitas Padjajaran, Bandung, 6-8 Juli 2010.

Evi Yulia Purwanti (2008), Analisis struktur pasar Kedelai sebagai alternative peningkatan posisi tawar petani.

Firdaus (2010). Analisis Daya Saing Kedelai di Jawa Timur. Jurnal J-SEP vol 32010

Hira, Anil \& Ron Hira (2000), The Institutionalism : Contradictory Notions of Change. Amarican Journal of Economics and Sociology, Vol 59 No 2, April : 267-282

Keban (1999), Diemensi-Dimensi Strategis Administrasi Publik, Yogyakarta:Kanisius

Mubyarto .1995, Pengantar Ekonomi Pertanian, Jakarta : LP3ES.

Nugroho, Riant, 2008, Public Policy, Yogyakarta:Gramedia.

Purwono \& Purnamawati, 2009, Budidaya 8 Jenis Tanaman Pangan Ungul, Jakarta:Penebar Swadaya

Rahayu Utami, 2006, Simulasi Dinamika Sistem Ketersediaan Ubi Kayu (studi Kasus Kabupaten Bogor), FTP, IPB,Bogor

Sadono Sukirno 1998, Pengantar Teori Makroekonomi. Jakarta:PT RajaGrafindo Persada.

Scott Pearson dan Sjaiful Bahri 2002, Policy Analysis Matrix (PAM), Universitas Jember, Jember.

Soekartawi 1995, Analisis Usahatani. Jakarta:Penerbit Universitas Indonesia (UI-Press).

Soetriono 2006, Daya Saing Pertanian dalam Tinjauan Analisis, Malang:Bayumedia Publishing. 